\title{
EFEKTIVITAS MACAM METODE APLIKASI PUPUK ORGANIK CAIR DAN DOSIS PUPUK KANDANG AYAM TERHADAP PENINGKATAN PRODUKSI CABAI RAWIT (Capsicum frutescens L.)
}

\section{THE EFFECTIVENESS OF KINDS OF LIQUID ORGANIC FERTILIZER APPLICATION METHODS AND THE DOSAGE OF CHICKEN CAGE FERTILIZER TO INCREASING PRODUCTION OF CAYENNE PEPPER (Capsicum frutescens L.)}

\author{
Istiqomah, Choirul Anam, Faris Zulkhilmi \\ Program Studi Agroteknologi Fakultas Pertanian \\ Universitas Islam Darul 'Ulum Lamongan Jawa Timur \\ Korespondensi : Zulkhilmifaris@gmail.com
}

\begin{abstract}
ABSTRAK
Penelitian ini dilaksanakan di Desa Karang tawar, Kecamatan Laren, Kabupaten Lamongan. Ketinggian tempat \pm 6 meter di atas permukaan laut (mdpl). Waktu penelitian dilaksanakan pada bulan Maret sampai Juni 2020. Penelitian ini menggunakan Metode Rancangan Acak Kelompok (RAK) yang disusun secara faktorial dengan dua faktor perlakuan yaitu Macam metode aplikasi POC Nasa (M) dan Dosis pupuk kandang ayam (D). Faktor Metode aplikasi terdiri 3 perlakuan yaitu: Tanpa aplikasi (MI), disemprot (M2), disiram (M3). Dosis Pupuk kandang Ayam terdiri dari 3 level yaitu: Pemberian 6 ton/ha (D1), Pemberian 10 ton/ha (D2), dan Pemberian 14 ton/ha (D3). Indikator pertumbuhan dan produksi yang diamati meliputi: Tinggi tanaman, Diameter batang, Jumlah Cabang, Banyak buah pertanaman dan Berat buah pertanaman. Pengamatan dilaksanakan mulai umur 14,28 hari dan dilanjut 42 hari sekali. Data hasil dari penelitian sejak tanaman berumur 14 hari hingga akhir pengamatan, dianalisa dengan analisa sidik ragam dan dilanjutkan dengan Uji BNT 5\%. Hasil penelitian menunjukkan bahwa terdapat interaksi antara perlakuan macam metode aplikasi POC Nasa. Kombinasi perlakuan terbaik adalah D3M3 (pemberian pupuk 14 ton/ha) pada parameter tinggi tanaman dan Diameter batang. Perlakuan macam metode aplikasi POC Nasa hampir seluruh parameter pengamatan. Dosis pupuk kandang ayam berpengaruh terhadap tinggi tanaman, jumlah Buah, jumlah Cabang, banyak Buah dan Berat buah.
\end{abstract}

Kata kunci : Cabai Rawit, Pupuk Kandang Ayam, Pupuk Organik Cair.

\begin{abstract}
This research was conducted in Karangtawar village, Laren sub-district, Lamongan district. Altitude \pm 6 meters above sea level (masl). The research was carried out from March to June 2020. This study used a randomized block design method (RBD) which was arranged factorial with two treatment factors, namely various methods of application of POC Nasa (M) and the dosage of chicken manure (D). The application method factor consists of 3 treatments, namely: without application (MI), sprayed (M2), watered (M3). The dose of chicken manure consists of 3 levels, namely: giving 6 tons / ha (D1), giving 10 tons / ha (D2), and giving 14 tons / ha (D3). The observed growth and production indicators included: plant height, stem diameter, number of branches, number of fruit crops and fruit weight per plant. Observations were carried out starting at the age of 14.28 days and continued once every 42 days. The result data from the research since the plants were 14 days old until the end of the observation, were analyzed with analysis of variance and continued with the $5 \%$ LSD test. The results showed that there was an interaction between the various treatments of the Nasa POC application method. The best treatment combination is D3M3 (fertilizer application of 14 tons / ha) on the parameters of plant height and stem diameter. Various treatment methods of POC Nasa application almost all the parameters of the observation. The dose of chicken manure affects plant height, number of fruits, number of branches, number of fruits and fruit weight.
\end{abstract}

Key words: Cayenne Pepper, Chicken Cage Fertilizer, Liquid Organic Fertilizer. 


\section{PENDAHULUAN}

Cabai rawit (Capsicum frutescens L.) merupakan salah satu tanaman hortikultura dari jenis sayuran yang memiliki buah kecil dengan rasa yang pedas. Cabai jenis ini dibudidayakan oleh para petani karena banyak dibutuhkan masyarakat, tidak hanya dalam skala rumah tangga, tetapi juga digunakan dalam skala industri, dan dieksport ke luar negeri. Tanaman ini mempunyai banyak manfaat terutama pada buahnya, yaitu sebagai bumbu masak, bahan campuran industri makanan. Selain buahnya, bagian lain dari tanaman ini seperti batang, daun, dan akarnya juga dapat digunakan sebagai obat obatan (Ashari, 1995).

Produksi tanaman cabai rawit dari tahun ke tahun terus meningkat, tahun 2009 produksinya sebesar 591.3 ton, sedangkan pada tahun 2010 produksinya sebesar 521.7 ton. Setahun terahir ini produksi tanaman cabai rawit mengalami penurunan sebanyak 69.6 ton (Deptan, 2011).

Selain pemupukan, upaya meningkatkan pertumbuhan dan produksi tanaman cabai dapat juga dilakukan dengan cara memperbaiki sifat fisik, kimia, maupun biologis tanah. Salah satu upaya memperbaikinya dapat dilakukan penambahan pupuk kandang yang merupakan pupuk organik dari hasil fermentasi kotoran padat dan cair (urin) hewan ternak yang dapat digunakan untuk memperbaiki sifat fisik, kimia, dan biologi tanah. Pupuk organik (pupuk kandang) mengandung unsur hara lengkap yang dibutuhkan tanaman untuk pertumbuhan dan produksi tanaman (Sanjaya, 2004).

\section{METODE PENELITIAN}

\section{Tempat dan Waktu Penelitian}

Penelitian ini dilaksanakan di Desa Karang Tawar,Kecamatan Laren, Kabupaten Lamongan. Ketinggian tempat \pm 6 meter di atas permukaan laut (mdpl). Waktu penelitian dilaksanakan pada bulan Maret sampai Juni 2020.

\section{Bahan Dan Alat}

Bahan
Benih yang digunakan dalam penelitian ini menggunakan varietas Bhaskara. Pupuk kandang yang digunakan adalah Kotoran ayam. Mulsa yang digunakan dalam penelitian ini adalah mulsa plastik hitam perak (MPHP) yang dibeli di depot pertanian. Pestisida yang digunakan dalam penelitian ini adalah pestisida nabati dan pestisida anorganik seperti Vegasus, bion-M 1/48 wp dan Dithane 45.

Alat

Alat-alat yang akan digunakan dalam penelitian ini berupa cangkul, garu, parang, hand spayer, meteran, gembor, ember, timbangan, pamplet nama, sketmat, tali, wadah (mangkuk), saringan, kaleng, ajir, gunting, alat tulis dan lain-lain.

\section{Pelaksanaan Penelitian}

1. Persiapan Pembuatan Pupuk Kandang Ayam dan Media Semai Media semai disiapkan sebelum persemaian dan pupuk kandang ayam dibuat sebelum media semai di lakukan dengan bahan campuran EM4 dan gula tetes merah lalu diratakan kemudian ditutup rapat selama 2 bulan sampai siap digunakan.

\section{Perlakuan Benih}

Benih yang digunakan dalam penelitian ini adalah benih cabai Varietas Bhaskara 10 gram.

\section{Penanaman Benih}

Sebelum benih ditanam terlebih dahulu media semai disiram hingga cukup basah, lalu media semai dilubangi pada bagian tengah babybag dengan kedalaman $1 \mathrm{~cm}$, kemudian barulah benih ditanam/diletakkan satu per satu bagian babybag yang telah dilubangi.

4. Pengolahan Tanah

Pengolahan tanah dilakukan dengan menggunakan cangkul, tanah yang diolah hanya bagian atas (top soil) dengan kedalaman $\pm 20 \mathrm{~cm}$. Setelah itu, tanah didiamkan selama satu minggu.

5. Pembuatan Plot

Pembuatan plot dilakukan setalah pengolahan tanah plot yang akan dibuat dalam penelitian ini berukuran $250 \times 230 \mathrm{~cm}$ dengan antar plot $50 \mathrm{~cm}$.

6. Pengaplikasian Pupuk Kandang 
Pengaplikasian pupuk kandang diberi dengan cara ditebar setelah plot jadi, pupuk kandang diberikan 15 hari sebelum tanam dengan dosis yang akan dicobakan per plot, kemudian dicangkul atau digemburkan hingga tercampur dengan tanah.

7. Pemberian Pupuk Dasar

Pupuk dasar diberikan 7 hari sebelum tanam. Pupuk dasar yang diberikan adalah Urea 25,2 gram/plot, SP-36 16,8 gram/plot, dan $\mathrm{KCl} 16,8$ gram/plot.

8. Pemasangan Mulsa

Pemasangan mulsa dilakukan pada siang hari sekitar jam 10 - 14 agar mulsa mudah dipasang karena sifatnya elastis. Setelah mulsa dipasang, lalau diberi penjepit yang dibuat dari bambu agar mulsa terpasang rapi. Pemasangan mulsa ini dilakukan 1 hari setalah pemberian pupuk dasar.

9. Pembuatan Lubang Tanam

Pembuatan lubang tanaman dilakukan 2 hari sebelum proses tanam. Pembuatan lubang dengan menggunakan kaleng yang dipotong melintang dengan diameter $8-10 \mathrm{~cm}$.

10. Penanaman

Penanaman ataupun pemindahan bibit ke lapangan dilakukan setelah bibit berumur \pm 28 hari setelah semai (HSS). Penanaman dilakukan pada sore hari dengan 4 tanaman perunit perlakuan/plot. Jarak tanam yang digunakan dalam penelitian adalah 50 × 60 $\mathrm{cm}$.
11. Aplikasi Pupuk Organik Cair (POC) Nasa Aplikasi POC Nasa dilakukan dengan cara penyemprotan menggunakan hand sprayer.

12. Pemeliharaan

a. Penyiraman

Penyiraman dilakukan setiap hari pada saat pagi hari, tergantung juga pada kondisi lingkungan setempat dan dilakukan sampai tanaman umur $15 \mathrm{HST}$, pada hari seterusnya kondisi lingkungan dalam keadaan penghujan.

b. Penyulaman

Penyulaman dilakukan apabila terdapat tanaman dalam keadaan sakit atau mati.

c. Perempelan/Pewiwilan

Perempelan atau pewiwilan tunas-tunas yang tumbuh diketiak daun pada batang utama tanaman cabai bertujuan untuk membentuk pertumbuhan vegetatif yang tegak dan kekar pada umur 3-4 minggu setelah tanam (MST).

d. Pemasangan Ajir

Pemasangan ajir pada tanaman dilakukan sedini mungkin 3 minggu setelah tanam (MST).

e. Pengendalian Hama dan Penyakit

Pengendalian hama dan penyakit dilakukan dengan menggunakan pestisida, bakterisida seperti Agript dan fungisida seperti Dithane M-45 dan Victory disemprot pada tanaman.

13. Panen

Pemanenen buah cabai dilakukan terhadap buah masak (yang sudah berwarna merah).

\section{Tinggi Tanaman}

\section{PEMBAHASAN}

Hasil analisis ragam menunjukan bahwa terjadi interaksi antara perlakuan dosis pupuk kandang ayam dan pemberian macam metode aplikasi POC Nasa terhadap tinggi tanaman pada umur 28 hst dan 42 hst. Hasil uji BNT 5\% seperti tabel dibawah in. Tabel 3. Rata-rata Tinggi Tanaman Cabai (cm) Pada Umur 28 dan 42 hst.

\begin{tabular}{|c|c|c|}
\hline \multirow[t]{2}{*}{ Perlakuan } & \multicolumn{2}{|c|}{$\begin{array}{c}\text { Rata-rata Tinggi Tanaman }(\mathrm{cm}) \text { pada } \\
\text { Pengamatan Umur }\end{array}$} \\
\hline & 28 hst & 42 hst \\
\hline Pupuk kandang ayam 6 ton/ha + Tanpa aplikasi & $17,29 \mathrm{c}$ & $34,07 \mathrm{~cd}$ \\
\hline $\begin{array}{l}\text { Pupuk kandang ayam } 6 \text { ton/ha+POC } \mathrm{N} \text { asa di } \\
\text { semprot }\end{array}$ & $23,27 \mathrm{~b}$ & $34,97 \mathrm{c}$ \\
\hline Pupuk kandang ayam 6 ton/ha +POC Nasa di siram & 31,13 a & $39,53 \mathrm{~b}$ \\
\hline Pupuk kandan ayam 10 ton/ha + Tanpa aplikasi & $22,23 \mathrm{~b}$ & $32,23 \mathrm{~d}$ \\
\hline $\begin{array}{l}\text { Pupuk kandang ayam } 10 \text { ton/ha + POC Nasa di } \\
\text { semprot }\end{array}$ & $23,18 b$ & $34,87 \mathrm{c}$ \\
\hline Pupuk ayam 10 ton/ha + POC Nasa cara di siram & $23,58 \mathrm{~b}$ & $40,87 \mathrm{~b}$ \\
\hline Pemberian pupuk 14 ton/ha + Tanpa aplikasi & $23,47 \mathrm{~b}$ & $33,93 \mathrm{~cd}$ \\
\hline
\end{tabular}


Pupuk kandang ayam 14 ton/ha+POC Nasa di

$23,64 b$

31,53 a

4,6

2,03

$34,07 \mathrm{~cd}$

43,67 a

di siram

BNT 5\%

Keterangan: Angka-angka yang diikuti oleh huruf yang sama dalam kolom yang sama tidak berbeda nyata dengan uji bnt $5 \%$.

Pada Tabel 3, dapat dilihat bahwa pengamatan parameter tinggi tanaman menunjukkan kombinasi perlakuan pemberian macam metode aplikasi POC Nasa dan dosis pupuk kandan ayam terhadap peningkatan produksi cabai pada pengamatan umur ,28 dan 42 hst. Pemberian pupuk 14 ton/ha + Pemberian dengan cara disiram (D3M3) dengan nilai 31,53 dan Pemberian pupuk 6 ton/ha + Pemberian dengan cara disiram dengan nilai 31,13 pada pengamatan umur 28 hst dan 42 hst Pemberian pupuk 14 ton/ha + Pemberian dengan cara di siram (D3M3) dengan nilai 43,67 terdapat interaksi pada pengamatan 28 dan 42 hst.

Jenis pemberian pupuk kandang ayam dan macam metode aplikasi POC Nasa pada tanaman cabai merah mempengaruhi pertumbuhan tinggi tanaman, cabai merah sehingga mempengaruhi tinggi tanaman. Menurut Tjitrosoepomo (1984) pertumbuhan terjadi pada jaringan meristem baik apikal maupun lateral.

Tabel 4. Rata-rata Tinggi Tanaman Cabai (cm) Pada Umur 14 hst.

\begin{tabular}{cc}
\hline & Rata-rata Tinggi Tanaman (cm) pada Pengamatan Umur \\
\cline { 2 - 2 } Perlakuan & $14 \mathrm{hst}$ \\
\hline Pemberian pupuk 6 ton/ha & $30,50 \mathrm{c}$ \\
Pemberian pupuk 10 ton/ha & $35,03 \mathrm{~b}$ \\
Pemberian pupuk 14 ton/ha & $39,14 \mathrm{a}$ \\
\hline BNT 5\% & 2,54 \\
\hline
\end{tabular}

Keterangan: Angka-angka yang diikuti oleh huruf yang sama dalam kolom yang sama tidak berbeda nyata dengan uji bnt $5 \%$

Pada Tabel 4. Dapat dilihat bahwa pada umur 14 hst terjadi perbedaan nyata pada dosis pupuk kandang ayam. Dapat dilihat bahwa D3 $(39,14)$ berbeda nyata dengan D1 $(30,50)$ dan D2 $(35,03)$ Hal ini dikarenakan perbedaan nyata tinggi tanaman

\section{Diameter Batang}

Hasil analisis diameter batang menunjukan bahwa terdapat interaksi antara perlakuan dosis pupuk kandang ayam dan pemberian macam metode aplikasi POC Nasa disebabkan pemberian dosis pupuk kandang ayam dan metode oplikasi POC Nasa, Hal ini karena pada konsentrasi tersebut unsur hara yang dibutuhkan tanaman tersedia dalam keadaan Tidak seimbang dan memicu peningkatan produksi tanaman cabai.

terhadap diameter batang pada umur 28 hst dan 42 hst Hasil uji BNT 5\% seperti tabel dibawah ini: 
Tabel 5. Rata-rata Diameter Batang Cabai (cm) Pada Umur 28 dan 42 hst.

\begin{tabular}{lcc}
\hline \multicolumn{1}{c}{ Perlakuan } & \multicolumn{2}{c}{$\begin{array}{c}\text { Rata-rata Diameter Batang (cm) } \\
\text { pada Pengamatan Umur }\end{array}$} \\
\cline { 2 - 3 } & $28 \mathrm{hst}$ & $42 \mathrm{hst}$ \\
\hline Pupuk kandang ayam 6 ton/ha + Tanpa aplikasi & $2,49 \mathrm{~b}$ & $5,25 \mathrm{bcd}$ \\
Pupuk kandang ayam 6 ton/ha+POC Nasa di semprot & $2,92 \mathrm{~b}$ & $5,27 \mathrm{bcd}$ \\
Pupuk kandang ayam 6 ton/ha +POC Nasa di siram & $2,91 \mathrm{~b}$ & $5,41 \mathrm{bc}$ \\
Pupuk kandang ayam 10 ton/ha + POC Tanpa aplikasi & $2,57 \mathrm{~b}$ & $5,15 \mathrm{~cd}$ \\
Pupuk kandang ayam 10 ton/ha + POC Nasa di semprot & $2,65 \mathrm{~b}$ & $5,78 \mathrm{ab}$ \\
Pupuk kandang ayam 10 ton/ha + POC Nasa cara di siram & $2,88 \mathrm{~b}$ & $5,32 \mathrm{bcd}$ \\
Pupuk kandang ayam 14 ton/ha + Tanpa aplikasi & $2,96 \mathrm{~b}$ & $5,25 \mathrm{bcd}$ \\
Pupuk kandang ayam 14 ton/ha+POC Nasa di semprot & $2,47 \mathrm{~b}$ & $4,75 \mathrm{~d}$ \\
Pupuk kandang ayam 14 ton/ha+ POC Nasa dengan di siram & $3,92 \mathrm{a}$ & $6,37 \mathrm{a}$ \\
\hline BNT 5\% & 0,68 & 0,63
\end{tabular}

Keterangan: Angka-angka yang diikuti oleh huruf yang sama dalam kolom yang sama tidak berbeda nyata dengan uji bnt $5 \%$

Pada Tabel 5, dapat dilihat bahwa pengamatan diameter batang tanaman menunjukkan kombinasi perlakuan pemberian macam metode aplikasi POC Nasa dan dosis pupuk kandan ayam terhadap peningkatan produksi cabai pada pengamatan umur 28 dan 42 hst Pemberian pupuk 14 ton/ha + Pemberian dengan cara di siram (D3M3) dengan nilai 3,92 pada pengamatan umur 28 hst dan 42 hst Pemberian pupuk 14 ton/ha + Pemberian dengan cara di siram (D3M3) dengan nilai 6,37 terdapat interaksi pada pengamatan 28 dan 42 hst.

Rata-rata Diameter batang pada tabel 5 bahwa pemberian POC Nasa dengan konsentrasi yang berbeda memberikan hasil yang berbeda nyata. Hal ini dikarenakan unsur hara yang dibutuhkan terpenuhi faktor lingkungan mendukung dengan baik. Haryati (2004) menjelaskan bahwa pemupukan melalui daun tidak untuk memenuhi unsur hara untuk keseluruhan tanaman tetapi hanya pupuk pelengkap. Hal ini sesuai dengan pendapat Widjojo (1999) yang menjelaskan bahwa ketersediaan unsur hara yang cukup

\section{Jumlah Cabang}

Hasil analisis jumlah cabang tanaman menunjukan bahwa terdapat interaksi antara dapat meningkatkan penyerapan hara, air, dan mineral yang dibutuhkan oleh tanaman, perbedaan komposisi unsur hara yang dikandung oleh masing-masing pupuk daun juga mengakibatkan perbedaan diameter pada tanaman.Pemberian pupuk 14 ton/ha + Pemberian dengan cara di siram (D3M3) dengan nilai 3,92 memberikan hasil terbaik Pemberian pupuk 14 ton/ha + Pemberian dengan cara di siram (D3M3) dengan nilai 6,37 terdapat interaksi pada pengamatan 28 dan 42 hst pada diameter pangkal batang umur 28 dan 42 HST. Wibawa (1998) yang menyatakan bahwa pemberian pupuk kandang ke dalam tanah dapat memperbaiki keadaan fisik tanah menjadi gembur, aerasi tanah menjadi lebih baik sehingga absorpsi unsur hara oleh tanaman akan lebih mudah. Pemberian pupuk kandang di samping menambah unsur hara juga mempertinggi humus, memperbaiki struktur tanah dan mendorong kehidupan jasad renik juga membantu menguraikan hara sehingga menjadi tersedia bagi tanaman dan memudahkan akar tanaman dalam penyerapan unsur hara (Dartius, 1990).

perlakuan dosis pupuk kandang ayam dan pemberian macam metode aplikasi POC Nasa 
terhadap jumlah cabang pada umur 28 hst dan 42 hst, sedangkan pada umur 14 hst tidak ada interaksi tetapi berbeda nyata pada perlakuan pupuk kandang ayam. Hasil uji BNT $5 \%$ seperti tabel dibawah ini:

Tabel 6. Rata-rata Jumlah Cabang Tanaman Cabai Pada Umur 28 dan 42 hst.

\begin{tabular}{lcc}
\hline \multicolumn{1}{c}{ Perlakuan } & \multicolumn{2}{c}{$\begin{array}{c}\text { Rata-rata Jumlah Cabang (cm) } \\
\text { pada Pengamatan Umur }\end{array}$} \\
\cline { 2 - 3 } & $28 \mathrm{hst}$ & $42 \mathrm{hst}$ \\
\hline Pupuk kandang ayam 6 ton/ha +Tanpa aplikasi & $10,27 \mathrm{c}$ & $24,73 \mathrm{~d}$ \\
Pupuk kandang ayam 6 ton/ha+POC Nasa di semprot & $10,67 \mathrm{c}$ & $26,21 \mathrm{~b}$ \\
Pupuk kandang ayam 6 ton/ha+POC Nasa di siram & $12,53 \mathrm{a}$ & $28,90 \mathrm{a}$ \\
Pupuk kandan ayam 10 ton/ha+tanpa aplikasi & $10,40 \mathrm{c}$ & $25,80 \mathrm{bc}$ \\
Pupuk kandang ayam 10 ton/ha+POC Nasa di semprot & $11,57 \mathrm{~b}$ & $25,27 \mathrm{bcd}$ \\
Pupuk kandang ayam10 ton/ha + POC Nasa cara di siram & $12,67 \mathrm{a}$ & $28,80 \mathrm{a}$ \\
Pupuk kandang ayam 14 ton/ha + Tanpa aplikasi & $10,67 \mathrm{c}$ & $26,07 \mathrm{~b}$ \\
Pupuk kandang ayam 14 ton/ha+POC Nasa di semprot & $12,63 \mathrm{a}$ & $24,80 \mathrm{~cd}$ \\
Pupuk kandang ayam 14 ton/ha+POC Nasa dengan di siram & $12,77 \mathrm{a}$ & $29,70 \mathrm{a}$ \\
\hline
\end{tabular}

Keterangan: Angka-angka yang diikuti oleh huruf yang sama dalam kolom yang sama tidak berbeda nyata dengan uji bnt $5 \%$

Pada Tabel 6, dapat dilihat bahwa pengamatan jumlah cabang tanaman menunjukkan kombinasi perlakuan pemberian macam metode aplikasi POC Nasa dan dosis pupuk kandan ayam terhadap peningkatan produksi cabai pada pengamatan umur 28 dan 42 hst Pemberian pupuk 14 ton/ha + Pemberian dengan cara di siram (D3M3) dengan nilai 12,77 pada pengamatan umur 28 hst dan 42 hst Pemberian pupuk 14 ton/ha + Pemberian dengan cara di siram (D3M3) dengan nilai 29,70 terdapat interaksi pada pengamatan 28 dan 42 hst.

Pada jumlah cabang menunjukkan perkembangan yang baik pada konsentrasi POC Nasa pada umur 28 dan 42 HST. Hal ini karena unsur hara yang dibutuhkan tanaman seperti unsur $\mathrm{N}$ tersedia dengan cukup dan dapat memicu perkembangan tanaman dengan baik dan didukung oleh faktor lingkungan yang baik pula. Leiwakabessy (1977) menyatakan bahwa pertumbuhan dan perkembangan tanaman sangat dipengaruhi oleh unsur hara yang tersedia, karena unsur hara yang berada dalam keadaaan optimum dalam jaringan tanaman akan memacu kegiatanmetabolisme dan pembentukan sel pertumbuhan. ketersediaan unsur hara yang cukup dan seimbang akan mempengaruhi proses metabolisme pada jaringan tanaman. Pemberian POC Nasa pada tanaman cabai dapat mempercepat sintesis asam amino dan protein sehingga mempercepat pertumbuhan tanaman. Hal ini sesuai dengan pendapat Rao (1994) yang mengatakan bahwa pupuk organik cair mengandung unsur yang berperan penting dalam metabolisme tanaman sehingga memungkinkan lancarnya proses-proses kesinambungan pemanjangan sel. Meningkatnya pertumbuhan dan perkembangan tanaman cabai pada dosis pupuk kandang Pemberian pupuk 14 ton/ha (D3M3) karena pada dosis tersebut unsur hara yang dibutuhkan oleh tanaman cabai dalam keadaan yang seimbang dan dapat memicu pertumbuhan tanaman dengan baik serta didukung juga dengan faktor lingkungan yang sesuai. 
Tabel 7. Rata-rata Jumlah cabang Tanaman Cabai Pada Umur 14 hst.

\begin{tabular}{cc}
\hline Perlakuan & Rata-rata Jumlah Cabang $(\mathrm{cm})$ pada Pengamatan Umur \\
& $14 \mathrm{hst}$ \\
\hline Pemberian pupuk 6 ton/ha & $6,80 \mathrm{c}$ \\
Pemberian pupuk 10 ton/ha & $8,13 \mathrm{~b}$ \\
Pemberian pupuk 14 ton/ha & $8,67 \mathrm{a}$ \\
\hline BNT 5\% & 0,4 \\
\hline
\end{tabular}

Keterangan: Angka-angka yang diikuti oleh huruf yang sama dalam kolom yang sama tidak berbeda nyata dengan uji bnt $5 \%$

Pada Tabel 7 . Dapat di lihat bahwa pada umur 14 hst terjadi perbedaan nyatanyata pada dosis pupuk kandang ayam. Dapat di lihat bahwa D3 $(8,67)$ berbeda nyata dengan D1 $(6,80)$ dan D2 $(8,13)$ Hal ini dikarenakan perbedaan jumlah cabang tanaman di sebabkan pemberian dosis pupuk kandang ayam dan metode oplikasi POC Nasa, Hal ini karena pada konsentrasi tersebut unsur hara yang dibutuhkan tanaman tersedia dalam keadaan tidak seimbang dan memicu peningkatan produksi tanaman cabai.

Tabel 8. Rata-rata Jumlah buah Pertanaman (cm) Pada Pengamatan panen

\begin{tabular}{lc}
\hline \multicolumn{1}{c}{ Perlakuan } & $\begin{array}{c}\text { Rata-rata Jumlah buah } \\
\text { Pertanaman (cm) pada } \\
\text { Pengamatan panen Kedua }\end{array}$ \\
\hline pupuk kandang ayam 6 ton/ha+ Tanpa aplikasi & $12,00 \mathrm{~d}$ \\
Pupuk kandang ayam 6 ton/ha+POC Nasa di semprot & $13,77 \mathrm{c}$ \\
Pupuk kandang ayam 6 ton/ha+POC Nasa di siram & $15,20 \mathrm{~b}$ \\
Pupuk kandan ayam 10 ton/ha + POC Tanpa aplikasi & $13,60 \mathrm{c}$ \\
Pupuk kandang ayam 10 ton/ha + POC Nasa di semprot & $14,03 \mathrm{bc}$ \\
Pupuk kandang ayam 10 ton/ha + POC Nasa cara di siram & $14,23 \mathrm{bc}$ \\
Pupuk kandang ayam 14 ton/ha+ Tanpa aplikasi & $13,43 \mathrm{c}$ \\
Pupuk kandang ayam 14 ton/ha+POC Nasa di semprot & $13,83 \mathrm{c}$ \\
Pupuk kandang ayam 14 ton/ha + POC Nasa dengan di siram & $18,37 \mathrm{a}$ \\
\hline
\end{tabular}

Keterangan: Angka-angka yang diikuti oleh huruf yang sama dalam kolom yang sama tidak berbeda nyata dengan uji bnt $5 \%$

Pada Tabel 8, dapat dilihat bahwa pengamatan jumlah buah pertanaman menunjukkan kombinasi perlakuan pemberian macam metode aplikasi POC Nasa dan dosis pupuk kandan ayam terhadap peningkatan produksi cabai pada pengamatan panen kedua Pemberian pupuk 14 ton/ha + Pemberian dengan cara di siram (D3M3) dengan nilai terbaik 18,37.

Meningkatnya jumlah buah pada masing-masing konsentrasi POC Nasa, dimana

\begin{abstract}
Jumlah Buah
Hasil analisis ragam menunjukan bahwa terdapat interaksi antara perlakuan dosis pupuk kandang ayam dan pemberian macam metode aplikasi POC Nasa terhadap jumlah buah per sempel pada panen kedua, sedangkan pada panen pertama berbeda nyata hanya pada perlakuan metode aplikasi POC Nasa.Hasil uji BNT 5\% seperti tabel dibawah ini:
\end{abstract}

Pertanaman $(\mathrm{cm})$ pada

$12,00 \mathrm{~d}$

$13,77 \mathrm{c}$

$14,03 \mathrm{bc}$

$14,23 \mathrm{bc}$

$13,43 \mathrm{c}$

$13,83 \mathrm{c}$

18,37 a jumlah buah cabai terbanyak dijumpai pada konsentrasi POC Nasa Pemberian pupuk 14 ton/ha (D3M3). 18,37, Hal ini karena pada konsentrasi tersebut unsur hara yang dibutuhkan tanaman tersedia dalam keadaan seimbang dan memicu peningkatan produksi tanaman cabai. Ketersediaan unsur hara yang cukup saat berkembangnya buah serta faktor penunjang mekanisme dari hasil fotosintesis yang ditranslokasi lebih cepat dari daun ke pembentukan buah. Pemberian pupuk 
kandang dengan dosis 14 ton/h memberikan hasil yang meningkat.

Tabel 9. Rata-rata Jumlah buah Pertanaman $(\mathrm{cm})$ Pada Pengamatan panen

\begin{tabular}{cc}
\hline Perlakuan & $\begin{array}{c}\text { Rata-rata Jumlah buah Pertanaman }(\mathrm{cm}) \text { pada } \\
\text { Pengamatan panen Pertama }\end{array}$ \\
\hline Tanpa aplikasi & $9,47 \mathrm{c}$ \\
Pemberian dengan cara di semprot & $9,93 \mathrm{~b}$ \\
Pemberian dengan cara di siram & $11,26 \mathrm{a}$ \\
\hline BNT 5\% & 1,6 \\
\hline
\end{tabular}

Keterangan: Angka-angka yang diikuti oleh huruf yang sama dalam kolom yang sama tidak berbeda nyata dengan uji bnt $5 \%$

Pada Tabel 9. dapat dilihat bahwa panen pertama terjadi perbedaan nyata pada dosis pupuk metode aplikasi pupuk organik cair (POC) Nasa Dapat di lihat bahwa M3 $(11,26)$ berbeda nyata dengan M1 $(9,47)$ dan D2 $(9,93)$ Hal ini dikarenakan perbedaan nyata jumlah buah per sampel di sebabkan Berat Buah

Hasil analisis ragam menunjukan bahwa terdapat interaksi antara perlakuan dosis pupuk kandang ayam dan pemberian pemberian dosis pupuk kandang ayam dan metode oplikasi POC Nasa Hal ini karena pada konsentrasi tersebut unsur hara yang dibutuhkan tanaman tersedia dalam keadaan Tidak seimbang dan memicu peningkatan produksi tanaman cabai.

macam metode aplikasi POC Nasa terhadap berat buah per sempel pada panen pertama dan kedua hst. Hasil uji BNT 5\% seperti tabel dibawah ini :

Tabel 10. Rata-rata Berat buah pertanaman (cm) Pada Pengamatan panen

Perlakuan
Rata-rata Berat buah pertanaman (cm) pada Pengamatan Kedua

\begin{tabular}{|c|c|}
\hline Pupuk kandang ayam 6 ton/ha+Tanpa aplikasid & $25,1 \mathrm{c}$ \\
\hline Pupuk kandang ayam 6 ton/ha+ POC Nasa di semprot & $34,7 a b$ \\
\hline Pupuk kandang ayam 6 ton/ha+POC Nasa di siram & $38,5 a b$ \\
\hline Pupuk kandan ayam 10 ton/ha+ POC Tanpa aplikasi & 31,5 bc \\
\hline Pupuk kandang ayam 10 ton/ha+ POC Nasa di semprot & $35,7 a b$ \\
\hline Pupuk kandang ayam 10 ton/ha+ POC Nasa cara di siram & $31,0 \mathrm{bc}$ \\
\hline Pupuk kandang ayam 14 ton/ha + Tanpa aplikasi & $31,5 \mathrm{bc}$ \\
\hline Pupuk kandang ayam 14 ton/ha+POC Nasa di semprot & $25,7 \mathrm{c}$ \\
\hline Pupuk kandang ayam 14 ton/ha+ POC Nasa dengan di siram & 42,1 a \\
\hline BNT 5\% & 8,5 \\
\hline
\end{tabular}

Keterangan: Angka-angka yang diikuti oleh huruf yang sama dalam kolom yang sama tidak berbeda nyata dengan uji bnt $5 \%$

Pada Tabel 10, dapat dilihat bahwa pengamatan berat buah pertanaman menunjukkan kombinasi perlakuan pemberian macam metode aplikasi POC Nasa dan dosis pupuk kandan ayam terhadap peningkatan produksi cabai pengamatan panen kedua Pemberian pupuk 14 ton/ha + Pemberian dengan cara di siram (D3M3) dengan nilai terbaik 42,1 pada pengamatan panen pertama dan kedua pada pengamatan berat buah pertanaman.

Penggunaan POC Nasa menunjukkan hasil yang baik pada berat buah cabai dari pada perlakuan lain. Hal ini sesuai dengan pendapat Hardjowigeno (2007) yang menyatakan bahwa penyerapan hara melalui mulut daun (stomata) berjalan cepat, sehingga perbaikan tanaman cepat terlihat. 
Selain itu, unsur hara yang diberikan lewat daun hampir seluruhnya dapat diambil tanaman dan lebih cepat diproses dalam fotosintesis dan ditranslokasikan dengan cepat sampai ke buah sebagai lumbung penyimpanan akan bertambah besar. Salah satu unsur hara makro dan unsur hara mikro yang terkandung dalam POC Nasa berupa K. Parman (2007) menyatakan unsur hara makro dan unsur hara mikro yang terkandung dalam pupuk organik cair menghasilkan pengaruh yang komplek terhadap pembentukan produksi karbohidrat. Kalium berperan dalam mengaktifkan enzim yang berperan dalam proses metabolisme karbohidrat, lemak dan protein.

Meningkatnya berat buah cabai cabai pada perlakuan pupuk kandang Pemberian pupuk 14 ton/ha + Pemberian dengan cara di siram karena pada dosis tersebut unsur hara $\mathrm{K}$ yang dibutuhkan oleh tanaman cabai tersedia dalam keadaan yang cukup dan dapat memicu produksi tanaman dengan baik serta didukung juga dengan faktor lingkungan yang baik. (Djuniwati et al, 2003) dalam Idris (2008) menyatakan bahwa bahan organik menghasilkan asam asam organik sehingga $P$ menjadi tersedia dalam tanah. Baharuddin (1989) dalam Idris (2008) menyatakan bahwa semakin tingginya serapan P-tanarnan menyebabkan proses metabolisme semakin baik sehingga pada akhirnya dapat meningkatkan pertumbuhan dan hasil tanaman cabai. Unsur fosfor pada tanaman berfungsi untuk merangsang pertumbuhan akar, berfungsi dalam transfer energi, pcnyusun protein sehingga menjamin lebih baiknya prose metabolisme dalam tanaman seperti proses transportasi dan alokasi fotosintesis.

Tabel 11. Rata-rata Berat buah pertanaman Cabai $(\mathrm{cm})$ Pada Pengamatan panen

\begin{tabular}{cc}
\hline & Rata-rata Berat buah pertanaman (cm) pada \\
\cline { 2 - 2 } Perlakuan & Pengamatan Pertama \\
\hline Tanpa aplikasi & $20,49 \mathrm{c}$ \\
Pemberian dengan cara di semprot & $21,51 \mathrm{~b}$ \\
Pemberian dengan cara di siram & $23,64 \mathrm{a}$ \\
\hline BNT 5\% & 3,9 \\
\hline
\end{tabular}

Keterangan: Angka-angka yang diikuti oleh huruf yang sama dalam kolom yang sama tidak berbeda nyata dengan uji bnt $5 \%$

Pada Tabel 11, dapat dilihat bahwa panen pertama terjadi perbedaan nyata pada metode aplikasi pupuk organik cair (POC) Nasa. Dapat di lihat bahwa M3 $(23,64)$ berbeda nyata dengan M1 $(20,49)$ dan M2 $(21,51)$ Hal ini dikarenakan perbedaan nyata berat buah per sampel di sebabkan

\section{KESIMPULAN}

\section{Simpulan}

Perlakuan Macam metode aplikasi POC Nasa dan dosis pupuk kandang ayam berpengaruh sangat nyata terhadap tinggi tanaman cabai pada umur 28 dan 42 HST dan juga berpengaruh sangat nyata terhadap diameter pangkal batang umur 28 dan 42 HST dan jumlah cabang umur 28 dan 42 HST. pemberian dosis pupuk kandang ayam dan metode oplikasi POC Nasa Hal ini karena pada konsentrasi tersebut unsur hara yang dibutuhkan tanaman tersedia dalam keadaan Tidak seimbang dan memicu peningkatan produksi tanaman cabai.

Perlakuan metode aplikasi POC Nasa Berpengaruh nyata terhadap tinggi tanaman pada umur 28,42 HST dan berpengaruh tidak nyata terhadap tinggi tanaman 14 HST.

Perlakuan pupuk kandang ayam berpengaruh sangat nyata pada tinggi tanaman 28 dan 42 HSTdan jumlah buah. Namun Perlakuan pupuk kandang ayam berpengaruh tidak nyata pada tinggi tanaman umur 14 HST.

Tidak terdapat interaksi yang nyata antara konsentrasi POC Nasa dan perlakuan pupuk 
kandang terhadap setiap perubahan yang diamati.

\section{Saran}

Perlu dilakukan penelitian lanjutan tentang berbagai macam metode aplikasi POC Nasa dan dosis pupuk kandang ayam terhadap produksi tanaman cabai. Dalam usaha budidaya tanaman cabai sebaiknya menggunakan dosis pupuk kandang ayam 14 ton/ha yang dikombinasikan dengan metode kosentrasi POC Nasa.

\section{DAFTAR PUSTAKA}

Anonymous. 2011. Ketingian tempat dan pertumbuhan Tanaman, Group Belajar sivikultur. Dalam http://www.silvikultur.com/ketinggia $\mathrm{n}_{-}$

Tempat_dan_pertumbuhan_Tanaman .html, Diakses pada tangal 12 desember 2011.

Arman S. 2007. Pengaruh Pemberian Pupuk Organik Cair terhadap Pertumbuhan dan Produksi Kentang (Solanum tuberosum L.). Buletin Anatomi dan Fisiologi, Vol. 15 (2): 21 - 31.

Ashari, S. 1995. Hortikultura, Aspek budidaya, Universitasindonesia. Jakarta.

Ballai Penelitian Sayuran. 2005 Budidaya Tanaman Cabai merah: panduan Teknis PPT cabai merah No. 2 lembag, Bandung. 44 halaman.

Dartius. 1990. Fisiologi Tumbuhan 2. Fakulitas Pertanian Universitas Sumatera Utara, Medan. HIm125.

Departemen pertanian [Deptan]. 2011. Besis data statistik pertanian. Dalam http://aplikasi,deptan,go.di, Diakses tanggal 15 juni 2011.

DJuniawati. 2003. Optimasi proses pengolahan mi jagung instan berdasarkan kajian preferensi konsumen. Skripsi. Departemen IImu dan Teknologi Pangan, Fakultas Teknologi Pertanian, Institut Pertanian Bogor, Bogor.
Hadisuznitro, 2002, Membuat Pupuk Organik Cair. Agromedia Pustaka. Jakarta.

Hardjowigeno, S. 2007. Ilmu Tanah. Akademika Pressindo. Jakarta.

Haryati, S. 2004. Pengaruh Dosis Pemberian Kapur Dolomit dan Penguaan Jenis Pupuk OrganikTerhadap Pertumbuhan Da Hasil Kedelai (Glycine max L.). Skripsi tidak dipublikasikan .Fakulitas Pertanian Universitas Muria Kudus.

Idris, m. 2008. Strategi \& Metode Pengajaran: Menciptakan Keterampilan Mengajar Yang Evektif Da Edukatif Yogyakarta: Ar-ruzz Media.

Leiwakabessy, F. 1977. Kesuburan Tanah. Diktat. Fakultas Pertanian IPB. Bogor.

Lingga, p. dan Marsono. 2001 Penunjuk Pengunaan pupuk. Penebar Swadaya, Jakarta.

Musnamar, E. 2003. Pupuk organik. Penebar Swadaya, Jakarta.

Nawangsih, A. 2003. Cabai Hat Beauty (edisi Revisi). Penebar Swadaya, Jakarta.

Ranklin P, dkk, Fisiologi Tanaman Budidaya Fisiologi

Tanaman 
Budidaya, Jakarta: Universitas Indonesia (UIPress), 1992

Rao, Subba. 1994. Mikroganisme Tanah dan Pertumbuhan Tanaman Edisi kedu. Jakarta: Universitas Indonesia.

Sanjaya, Y. 2004. Penggunaan pupuk Terhadap Tanaman. Jurnal of Biological science, Biosmart .vol 6 nomor 2.

Setiadi, 2007. Konsep dan Penulisan Riset keperawatan.cetakan pertama. Graha ilmu. Yogyakarta.

Setiadi. 2005. Bertanam Cabai. Penebar Swadaya, Jakarta.

Setiadi. 2007. Jenis dan Budidaya Cabai Rawit, penebar Swadaya, Jakarta
Sunarjono, H. 2006 bertanam 30 jenis sayur. Penebar. Swadaya. Jakarta 184 halaman.

Susanto, R. 2002. Pertaniaorganik: Menuju Pertanian Alternatif dan Berkelanjutan. Buku cetakan ke1.kanisius. Yogyakarta. 218 p.

Sutanto. 2002. Pertanian organik, menuju pertanian alternatif dan Berkelanjutan Kanius, Yogyakarta

Tjitrosoepomo, Siti Sutarni. 1984. Botani Umum. Bandung: Angkasa.

Wibawa, G. 1998. Dasar-Dasar Fisiologi Tanaman. Suryandra Utama. Semarang.

Widjojo, P. 1999. Pengaruh Pupuk Daun, Penerba Swadaya, Jakarta. 